Article

\title{
United in Diversity? A Study on the Implementation of Sanctions in the European Union
}

\author{
Francesco Giumelli ${ }^{1, *}$, Willem Geelhoed ${ }^{2}$, Max de Vries $^{3}$, and Aurora Molesini ${ }^{4}$ \\ ${ }^{1}$ Department of International Relations and International Organization, University of Groningen, The Netherlands \\ 2 Department of Criminal Law and Criminology, University of Groningen, The Netherlands \\ ${ }^{3}$ Department of Transboundary Legal Studies, University of Groningen, The Netherlands \\ ${ }^{4}$ Department of Law, University of Bologna, Italy \\ * Corresponding author (f.giumelli@rug.nl)
}

Submitted: 15 July 2021 | Accepted: 16 November 2021 | Published: 26 January 2022

\begin{abstract}
The implementation of European Union (EU) policies has been investigated for several policy areas, but Decisions made under the Common Foreign and Security Policy (CFSP) have rarely been considered. While many CFSP measures are applicable throughout the EU without the need for further action on the domestic level, some Decisions must be implemented by Council Regulations. These Council Regulations adopted with the intent to implement CFSP Decisions have qualities of Directives, which delegate implementing tasks to member states and require transposition. The aim of this article is to investigate whether restrictive measures imposed by the EU are uniformly implemented across the member states, and, if not, to what extent implementation performance varies. We observe significant differences in implementation performance across member states. The findings of this article are twofold. First, we claim that implementation and compliance studies should involve CFSP decisions more systematically. Second, empirical confirmation is provided of how uneven transposition and application occurs also in CFSP matters. This study is based on empirical work that consisted of desk research and semi-structured interviews with national competent authorities of $21 \mathrm{EU}$ member states taking place between March 2020 and January 2021.
\end{abstract}

Keywords

CFSP; European Union; implementation; sanctions

Issue

This article is part of the issue "Beyond Foreign Policy? EU Sanctions at the Intersection of Development, Trade, and CFSP" edited by Katharina Meissner (University of Vienna) and Clara Portela (University of Valencia).

(C) 2022 by the author(s); licensee Cogitatio (Lisbon, Portugal). This article is licensed under a Creative Commons Attribution 4.0 International License (CC BY).

\section{Introduction}

The implementation of European Union (EU) policies at the national level is the centre of attention in European studies (Mastenbroek, 2005). The past few decades have seen studies on the implementation of environmental policies, transportation rules, and equal treatment measures, among other areas (Bache, 1999; Blom-Hansen, 2005; Bugdahn, 2005). However, scholarship has rarely considered Decisions made under the Common Foreign and Security Policy (CFSP; Bicchi, 2010; Wunderlich, 2012). This lack of attention paid to the implementa- tion of foreign policy measures is clearly unwarranted. While many CFSP measures are applicable throughout the EU without the need for further action on the domestic level, some Decisions adopted under the CFSP must be implemented by Council Regulations containing more stringent requirements for member states in terms of implementation and oversight (Giumelli, 2013, 2019). These Council Regulations frequently delegate tasks to member states, for instance they ask the latter to define penalties applicable to infringements. As such, Council Regulations adopted with the intent to implement CFSP Decisions have qualities of 
Directives, which delegate implementing tasks to member states and require transposition. Although the Treaty of Maastricht attributed CFSP competences to the EU already in November 1993, and foreign policy success is dependent on member states coordinating their deeds, the domestic implementation of CFSP Decisions and the related Regulations has received surprisingly little attention from researchers. This research aims, then, to address this lack of scrutiny.

The article focuses on the domestic implementation of EU foreign policy. More specifically, the aim here is to investigate whether restrictive measures imposed by the EU are uniformly implemented across member states, and, if not, to what extent implementation performance varies. In doing so, we focus our attention on restrictive measures as an example within the broader field of foreign policy. The area of restrictive measures is particularly interesting because it contains instruments that require strict implementation on the domestic level, while at the same time leaving some room for member states to choose the method of implementation. This naturally creates the possibility of uneven implementation. Indeed, we observe significant differences in implementation performance (also implementation variance) across member states. To this end, we analysed restrictive EU measures as an illustrative case of how foreign policy and internal-market rules are interrelated. We adopt Duina's (1997) multifaceted definition of "implementation," which understands the latter as a three-dimensional concept composed of the transposition of legislative acts, their application, and the enforcement of policies. Within the scope of this analysis, we focus exclusively on transposition and application. Regarding transposition, we look at the maximum penalties set for sanctions violations under administrative and criminal law. Regarding application, we examine the institutional architecture of export procedures in all EU member states. Thus, we carry out empirical research consisting of desk research and semi-structured interviews with national competent authorities of $21 \mathrm{EU}$ member states taking place between March 2020 and January 2021.

The article is divided into five sections. Section 1 reviews the literature on EU implementation to show the research gap in the area of CFSP. Section 2 introduces the restrictive-measures policy of the $\mathrm{EU}$ in highlighting the institutional overlap between the former first and second pillars. Section 3 introduces the conceptual framework upon which we base the empirical observations. Section 4 presents the empirical findings of the research. Section 5 discusses potential trends that emerge from the analysis and identify their relevance. Finally, we conclude by reviewing the main empirical findings of the article and by shedding light on future research avenues.

\section{What Do We Know About Uneven Implementation?}

The topic of policy implementation does not originate in EU studies, but is a typical problem for any public policy that is implemented by complex organizations (Pressman \& Wildavsky, 1984). In general terms, policy implementation can be viewed both from a top-down and a bottom-up perspective. In the top-down perspective, central authorities tend to retain decision-making powers and this approach privileges a standardized outcome with lower-level actors not foreseen as having discretionary power. The main problem of this approach is that the central legislators are unaware of the details of local conditions and have limited resources, therefore failures in implementation are explained by lack of clarity in the provisions and scarcity of means to appropriately implement policies (Meter \& Horn, 1975; Sabatier \& Mazmanian, 1979). Conversely, the bottom-up approach views the role of local implementers in shaping the policy outcome by exercising a wider discretionary power assigned by the central authority to the periphery. However, the variance of implementation practices and the concomitant needs for flexibility then constitute the core of the problem, since either the policy outcome will be unequal or the requests and desires from local authorities will be too demanding (Hjern, 1982; Lipsky, 1980).

The implementation of EU legislation within member states has contributed significantly to the debate on EU integration (Falkner et al., 2005; Mastenbroek, 2005; Sverdrup, 2005), but the central concept for academic debate in European studies became the one on Europeanization (Cowles et al., 2001; Héritier, 2001). This concept referred to the idea that EU member states over time would adopt policies more in line with European rather than exclusively with national interests and, consequently, transform their practices to mirror EU standards (Chatzopoulou, 2015; Sampson Thierry \& Sindbjerg Martinsen, 2018). Whereas the Europeanization debate focused on how the EU influences the domestic "polities, politics, and policies," others investigated the way in which member states implement EU legislation. As described by Versluis, Van Keulen, and Stephenson, "the main issue addressed in these studies has been how to explain variations in the implementation of EU legislation between member states" (Versluis et al., 2011, p. 192; also see Steunenberg \& Toshkov, 2009). For instance, Treib (2014) elaborated a typology with four categories of states and respective explanations. Another analytical framework is offered by Di Lucia and Kronsell (2010), who write about the "willing, unwilling, and unable" in their analysis on how the EU Biofuels Directive was poorly implemented in member states. Yet another study by Börzel et al. (2010) found that powerful member states are most likely to violate EU laws, whereas smaller ones with efficient bureaucracies are the most compliant.

This can often imply that, in a certain policy area, transposition will occur unevenly across the EU or implementation performance will vary (Thomann \& Sager, 2017). Some researchers have looked at the substance, scope, and effort in analysing implementation performance with a case study in the field of environmental 
policy (Bondarouk \& Mastenbroek, 2018). Others have focused on the role of street-level bureaucrats in implementation with a bottom-up approach preferred to a top-down one as suggested by compliance studies (Dörrenbächer, 2017; Sampson Thierry \& Sindbjerg Martinsen, 2018; Schmälter, 2019). Several areas pertaining to the internal market have been discussed. Without the possibility to do justice to a very rich debate, examples of these are tax crimes (Rossel et al., 2021), air quality in Germany (Gollata \& Newig, 2017), cohesion policy (Blom-Hansen, 2005), social policy (Hartlapp \& Leiber, 2010), regional policy (Bache, 1999), and environmental policy (Börzel \& Buzogany, 2019; Bugdahn, 2005). Migration has also received scholarly attention (Wunderlich, 2012). The growing gap in implementation performance led some to consider "one-size-fits-all solutions [to be] often neither politically feasible nor normatively desirable" (Falkner et al., 2005, p. 1). This has also been explored as "gold-plating" and "customization" practices across the EU, with a focus on Justice and Home Affairs and environmental policies (Thomann \& Zhelyakova, 2017). At the other extreme, certain scholars have also discussed cases of non-compliance (Börzel, 2021; Börzel et al., 2010; Falkner et al., 2004; Siegel, 2011)

In this rich debate on effective implementation, implementation performance, and non-compliance, CFSP matters have rarely been investigated however. Recent efforts at studying the implementation of restrictive measures (Drulakova \& Zemanova, 2020; Lohmann \& Vorrath, 2021) suggest that coordinated action within the EU is necessary to ensure that foreign policy decisions have higher chances of success. Therefore, there is a clear societal relevance for studying variance in the transposition of EU policy measures. This article intends to close this research gap in two ways. First, it contributes to defining a fuller picture of EU implementation studies by including CFSP matters and, second, it provides an empirical study on even and uneven transposition of EU decisions by focusing on sanctions policy.

If CFSP decisions require common-market adjustments, this means that a review of the fundamental principles constituting the internal market is necessary. Uneven transposition practices could cause economic operators to benefit more from activity in some member states than in others. In other words, uneven transposition in CFSP matters would have similar effects on the internal market as in other policy areas.

Moreover, even transposition in CFSP matters is necessary to ensure coherent external action. If economic operators face different rules in different member states, foreign policy actions easily become inconsistent across time and space. For instance, while restrictive measures suggest that certain forms of trade should not take place, some transactions will still occur via particular member states if EU measures are not transposed evenly across the board. This can undermine the effectiveness of EU foreign policy action.
The next section describes the policymaking process in the area of sanctions, and illustrates how the behaviour of member states can have a significant impact on the effectiveness of EU foreign policy decisions.

\section{EU Sanctions: When Council Regulations Are Used As If They Were Directives}

The EU resorts to sanctions via three different avenues. First, it transposes Security Council Resolutions imposing sanctions according to Chapter VII of the United Nations Charter (de Vries \& Hazelzet, 2005). Second, it can suspend preferential agreements as per Article 96 of the Cotonou Agreement when a signatory party has been found to be in violation of human rights (Portela, 2007). Finally, it has been able to use sanctions as one of its CFSP instruments since the entry into force of the Treaty of Maastricht in 1993 (Giumelli et al., 2021). Certainly, cooperative efforts had taken place also before then, such as in the cases of the Soviet Union in 1981 and Argentina in 1982 as well as Myanmar in 1988 and China in 1989 (Kreutz, 2005), but it was only with the end of the Cold War and the transformation of the European Community into a political union that the authority to impose sanctions (in EU jargon: "restrictive measures") would be attributed to the EU (Eriksson, 2011; Portela, 2010). This article will focus exclusively on the latter.

The legal basis for a common foreign policy is Article 29 of Chapter Two of Title V of the Treaty of the European Union (TEU) on "Specific Provisions on the Common Foreign and Security Policy." While Chapter One indicates the general provisions on the Union's External Action, Article 29 allows the EU to "adopt decisions which shall define the approach of the Union to a particular matter of a geographical or thematic nature." Among these decisions are also those imposing restrictive measures, such as arms embargoes, travel bans, financial and trade restrictions.

CFSP decisions normally assume that member states comply with them, but the implementation of restrictive measures requires further steps to be taken. It comes with no surprise that the same Article 29 states that "Member States shall ensure that their national policies conform to the Union positions." The need for coordination is recognized by the EU-led efforts to set Basic Principles (European Union, 2004), Guidelines (European Union, 2018a), and Best Practices (European Union, 2018b). These three documents attempt to address the challenge of reducing the divergent practices that characterize the implementation of sanctions, but there still exists significant potential for uneven transposition.

Travel bans are the only measures that do not require additional EU legislation because their implementation falls under the responsibilities of individual member states. Travel bans restrict access to the territories of the member states and therefore to the EU. Decisions taken under Article 29 of the TEU create the legal basis for EU member states to deny entry and/or passage to their 
own territories, but the latter ultimately have the final say on entry and on granting exemptions.

Arms embargoes show how sanctions have contributed to blurring the separation between the CFSP and other EU policy areas. Arms embargoes prohibit the sale of weapons and related technology or services to individuals, non-state entities, and to states per se. On the one hand, arms embargoes are established with EU Council Decisions; the final decision on an arms sale is to be taken by the member state in question based on a national-security clause added to the Treaty of Rome in 1957. However, the EU has adopted two documents that "guide" member states in making their considerations/final assessments on arms exports. First, the EU adopted a "Common Military List" that indicates what equipment and technologies are to be covered by arms embargoes (Council Common Position of 8 December 2008, 2008). Second, since it was soon evident that several items produced for civilian use could also be utilized for military objectives, a list of dual-use items was adopted in a 2009 Regulation (Council Regulation of 5 May 2009, 2009). Consequently, member states must authorize the export of items that can be used for both civilian and military purposes (Council Regulation of 5 May 2009, 2009). Both lists are regularly updated. This Regulation is directly applicable to all EU entities, so exporters who think that certain goods might fall under such a listing must apply for an export licence from the competent national authorities, such as the Ministries for Economics and Foreign Affairs in their own member state.

The implementation of trade and financial restrictions require both EU and member-state actions. Financial sanctions include the freezing of assets and the prohibition of providing loans and making payments to individuals and entities. Trade restrictions entail the prohibition on selling specific products or services to a targeted country, region, company, and/or individual. As such, CFSP decisions adopting economic measures also require a Council Regulation, as per Article 215 of the Treaty on the Functioning of the European Union (TFEU), which is directly applicable across the Union. However, Council Regulations regarding CFSP retain qualities proper to Directives, such as the request to member states to take steps towards full implementation of the Council Regulation, de facto asking them to move towards completion in the spirit of the Regulation. For instance, member states have to establish penalties in their national laws for violations of sanctions regulations. They also carry the responsibility to grant exemptions and exceptions on humanitarian grounds. Similarly to the arms-control regime, each member state is to indicate a national competent authority to be contacted with questions regarding sanctions and export control. These implementation duties of the member states can easily lead to institutional diversity and divergent punishment across member states, and thus contribute to uneven implementation.

In sum, the EU has delegated different kinds of decision-making powers to member states on the imple- mentation of these four types of restrictive measures. For travel bans, member states receive specific guidelines with regards to listed individuals and generic guidelines regarding general categories of non-listed individuals and of exemptions. On arms embargoes and dual-use goods, member states receive more specific guidelines regarding the granting of export licences, but the qualitative assessment of each request is mainly left in the hands of national competent authorities. When it comes to financial and trade restrictions, all actors are bound by Council Regulations-as with any other Regulation adopted in policy areas falling under the exclusive and shared competences of the EU, with member states being asked to take further action. This is where uneven transposition can occur.

The fact that CFSP measures are implemented by Council Regulations using a legal basis relating to the internal market has allowed the Court of Justice of the European Union (CJEU) to extend its scrutiny to these CFSP measures. Since restrictive measures are defined in Council Decisions, they should not be subject to CJEU scrutiny. However, as seen above, their implementation takes place through Council Regulations, which fall under the competences of the Court. Initially, individuals appealed against restrictive measures insofar as their fundamental rights were herewith violated, but the Court often rejected these claims on the basis that sanctions were CFSP decisions and, therefore, beyond their control. The Kadi judgement in 2008 changed this paradigm; it recognized that Council Regulations implementing Council Decisions were adopted under the internal-market competence. Therefore, individuals can take legal action and require the intervention of the Court (Eckes, 2008). The CJEU's review of CFSP Decisions occurs via the Council Regulations necessary for implementation, which further confirms the link between sanctions and EU legislation.

\section{Theoretical Notes}

The focus of this research is on variance in implementation across EU member states. We rely, as noted, on a threefold conceptualization of "implementation" consisting of transposition, application, and enforcement (Duina, 1997). Transposition refers to the adaptation of the domestic legal system to meeting the needs of a legislative instrument adopted at the EU level, normally a Directive. Application refers to using the relevant policy provisions in processes and procedures on the domestic level, mostly by government authorities. Finally, enforcement refers to actions undertaken by national authorities to maintain compliance with the policy in question and to impose penalties in case of violations. In this investigation, we will focus exclusively on transposition and application.

Normally, transposition of EU law is a key activity for member states so as to comply with a Directive; this activity would be unnecessary in case of Regulations 
due to their direct applicability. However, sometimes member states have to make legislative changes to fully acknowledge the requirements of a given Regulation. This is the case with restrictive measures since, as noted above, Council Regulations in these matters delegate specific tasks to member states. One of the common provisions, which can be found in most Regulations, is to "lay down the rules on penalties applicable to infringements," which contains the obligation that "penalties provided for must be effective, proportionate and dissuasive." In order to evaluate variance in implementation, we look at administrative and criminal law penalties for sanctions violations. We acknowledge that comparing penalties provisions in national legal systems could provide a partial picture of the reality on the ground. However, examining maximum sentences provides an idea of the type of criminal penalties that can be applied in case of infringements, and it is a proxy variable to make observations on how non-state actors assess the risk of trade transactions that can fall under a sanctions regulation.

Application, in this context, refers to the institutional framework that member states create to administer restrictive measures. Member states are expected to set up an institutional framework that is able to guide economic operators, namely firms and companies, to a clear understanding of the processes and regulations regarding exports to non-EU countries. This is relevant because opaque institutional environments constitute an obstacle to the correct functioning of the internal market and undermine the effectiveness of sanctions. In general, member states have chosen different institutional solutions regarding the implementation of EU law. In presenting these, we will use Heidbreder's (2017) typology of centralization, "agencification," convergence, and networking to compare the different institutional settings established by member states to administer sanctions decisions. This typology allows us to go beyond the dichotomy between compliance and non-compliance. Instead, we can identify patterns in implementation and compare different EU member states' practices.

\section{Methodological Notes}

In order to empirically analyse the two issues outlined above, we carried out preliminary desk research and contacted the national competent authorities of respective EU member states with two sets of questions. These related to (a) the applicable criminal and/or administrative law on violations of EU sanctions, and to (b) the institutional architecture of restrictive measures. Our desk research covered 12 member states, all in Western and Southern Europe (see Table 1 in the Supplementary File). We selected these member states based on our command of their national languages and our knowledge of their legal systems.

The empirical research complements our desk work. In this, we researched the same questions that we posed to the competent authorities of the various member states. National competent authorities were contacted using the available information on the websites of the authorities mentioned in the Annexes to the sanctions Regulations (Commission Implementing Regulation of 5 July 2019, 2019). We also compiled a list of secondary competent authorities in the relevant member states in case a contacted authority was not willing to participate. Each national competent authority was contacted up to five times either via e-mail, telephone, or both. In total, 21 member states responded and we received questionnaires from 15 national competent authorities. We received a completed questionnaire from six of the 12 member states included in the desk research, and we did not find any conflicts between the desk research and the questionnaires. For the other six member states, we base our findings solely on the desk research. Of the 12 who decided not to complete the questionnaire, four notified us that they did not intend to do so, two expressed interest but did not complete the task, and six never responded at all (see Table 1 in the Supplementary File for a full list). The answers provided by the competent authorities complemented the preliminary findings, allowing us to formulate an exhaustive overview of the different legal and institutional frameworks for most EU member states.

\section{Transposition: Penalties}

Without directly assessing whether penalties are effective, proportionate, and dissuasive, we observe considerable differences across member states in terms of minimum and maximum penalties set for sanctions violations. Most member states only have criminal penalties for sanctions violations. Some member states, namely Belgium, Germany, Italy, Lithuania, and Romania, have both administrative and criminal penalties, whereas Poland and Spain only have administrative penalties. Note that Germany and Italy have administrative and criminal penalties for natural persons, but only administrative penalties for legal persons, as corporate criminal liability does not exist in these member states. Obviously, a downside of only prescribing administrative penalties is that the offender cannot be imprisoned, since being sent to jail is a criminal penalty. The absence of imprisonment as a penalty in Poland and Spain is unique, given that almost all other member states' criminal laws provide for lengthy jail sentences. In general, the maximum prison sentence for sanctions violations in member states' criminal laws is about three to six years. The lowest maximum prison sentences are four months in Denmark, which is increased to four years under particularly aggravating circumstances, and two years in Cyprus. The highest maximum prison sentences are 12 years in Malta and 15 years in Germany, under certain aggravating circumstances. The maximum prison sentences in Croatia and the Czech Republic depend on the type of sanction violated, with violations of trade/export 
restrictions being punished more severely. Surprisingly, Romanian criminal law only prescribes prison sentences for violations of sanctions related to dual-use goods and technologies; all other sanction violations cannot be punished with jail time.

The maximum fines under administrative and criminal law vary widely across member states. This variation is even larger because some member states calculate fines based on daily rates, which are country-specific, and on the income (turnover) of the offender. Maximum fines are generally higher for legal persons than for natural persons. The maximum fines permitted by member states' laws range from approximately a few hundred thousand euros to millions of euros to unlimited amounts. There are some notable exceptions with relatively low maximum fines, however. In Lithuania, the maximum administrative fine is only 6,000 EUR, whilst the maximum criminal fine is 200,000 EUR. In France, the maximum fine is based on the monetary amount involved in the offence, in relation to sanctions usually the value of the assets: For natural persons, the fine can be up to twice the monetary amount of the offence; for legal persons, this is 10 times the monetary amount of the offence. In case the latter is low, then only a relatively modest fine can be imposed. In the Netherlands, the standard maximum fine is only $87,000 \mathrm{EUR}$, although this can be increased to 870,000 EUR under aggravating circumstances and can be increased even further for legal persons to 10 percent of their annual turnover if this is deemed fitting to the crime. The most notable exception of all, however, is Romania, where the maximum fine for sanction violations is 30,000 RON $(\approx 6,000$ EUR) for both natural and legal persons. This is notable because, under Romanian criminal law, imprisonment is only possible for violations of sanctions related to dualuse goods and technologies, meaning that in all other cases of sanction violations the most severe penalty is only an extremely low fine. Thus, Romania's maximum penalties are exceptionally low compared to the rest of the EU. Table 3 in the Supplementary File shows the maximum prison sentences and fines for natural persons, and the maximum fines for legal persons for the 21 member states considered in the research.

\section{Application: The Institutional Framework}

In order to apply sanctions and, occasionally, to impose penalties, member states rely on their institutional frameworks. Contrary to the principles of an internal market, we observe that there are a plethora of different institutions that can be involved across the respective member states. This increases, therefore, the transaction costs for actors working in multiple countries and provides different incentives according to the main country of operation for any actor, be it a firm or a nongovernmental organization.

The starting point for our empirical investigation was the list of competent authorities provided by the mem- ber states themselves to the EU. The list of competent authorities is meant to provide a contact point in each member state that serves in support of both institutional and commercial actors. In the majority of cases, we were able to communicate efficiently with national authorities. However, we were surprised that not all contacts were working and/or accurate, as in the cases of Greece, Hungary, Italy, and Spain. It was possible to recognize a certain degree of complexity within domestic public administrations, as on several occasions we were invited to contact other offices or, less frequently, we received no further support.

Many member states have organized their procedures such that there is a need for cooperation among the multiple institutions responsible for specific activities. Competent authorities include the Ministry of Defence (MD), Ministry of Economy (ME), Ministry of Finance (MF), Ministry of Foreign Affairs (MFA), Customs authorities, and central banks (CB). The main functions covered by the competent authorities are the authorization and enforcement of sanctions. Specifically, the ME and MFA are often responsible for granting authorizations, whereas member states rely on the MF, Customs authorities, and national $C B$ for monitoring violations and enforcing sanctions. Our findings show divergent approaches as to the number of institutions involved in the implementation process, which oscillates from complex networks to single entities. Examples of these dimensions can be found respectively in the case of Malta and Spain. In the latter, there are two main competent authorities: First, the Secretary of State for Commerce under the Ministry of Industry, Tourism and Commerce, which is the supervisor of trading sanctions, the dual-use regime, export, and investment authorizations, and, second, the Ministry of Economic Affairs and Digital Transformation, which oversees the freezing of funds and money transfers through the Sub-Directorate General of Inspection and Control of Capital Movements. By contrast, in Malta the set of functions for the implementation of sanctions is attributed to a single authority: the Sanctions Monitoring Board.

There are certain ministries that are very often involved. For instance, the responsibility for granting authorizations in respect of funds, financial assistance, financing, as well as the freezing of funds is often attributed to the ME. This is the case for countries such as Germany, Luxembourg, and Romania. However, there are cases where authorizations are issued by the MF, for example in Poland, or, in the specific case of dual-use and military products, the MFA and MD. With respect to enforcement, the MF, Customs authorities, and national $C B$ play a central role in the vast majority of cases. Interestingly, the roles of institutions such as the $\mathrm{CB}$ or the MFA can vary significantly. These institutions focus either on coordination and supervision or on decisionmaking and granting authorizations, depending on the regime in force. Moreover, independently of their roles, in most member states national CBs are responsible 
for supervising compliance with EU law by other financial institutions.

\section{Discussion}

Empirical analysis of the implementation of Council Regulations on restrictive measures by EU member states confirms that the CFSP is an interesting and, as of yet, under-investigated area for studying how EU decisions are transposed and applied.

Overall, restrictive measures are implemented very differently across the EU. The degree of variation is fairly sizeable. The data-collection process revealed that uneven application is an issue even in the mere attempt to contact national competent authorities. We found that some member states employ extensive websites that are easy to navigate, and that some competent authorities are reachable without any problems. However, there are also incorrect contact details listed for competent authorities in Council Regulations and one can encounter cases of unresponsiveness via e-mail and phone when trying to contact national competent authorities. The 12 countries that did not return our requests are representative of the whole population of EU member states, as they include large and founding members (France), Nordic countries (Sweden), small countries located in Southern Europe (Cyprus, Greece, Malta, and Portugal), member states in Eastern Europe (Hungary, Latvia, Slovakia, and Slovenia), as well as wealthy Union members (Austria and Luxembourg).

Penalty levels vary significantly across EU member states. Indeed, prison sentences vary from a maximum of 15 years (although only for specific and graver violations) in Germany to being completely unavailable in Poland and Spain, which have opted for administrative penalties only. The same can be said for fines, which can also range from a few thousand euros, such as in the case of Romania, to penalties of many million euros, such as in the case of Estonia, to unlimited penalties, such as in the case of Croatia. The risk assessment changes substantially if even only the administrative penalties are substantially higher in one member state compared to another.

Uneven application is also the norm regarding the variety of institutional settings and the clarity of information available to economic operators. The aforementioned typology suggested by Heidbreder (2017) - centralization, agencification, convergence, and networking-provides some guidance in seeking to understand the various institutional structures in the respective member states. In general, we observe that top-down approaches (i.e., centralization and agencification) are quite frequent. We found instances of rather centralized and coordinated offices that do provide full information and specific guidelines on how sanctions ought to be implemented. All member states appear to have centralized the decision-making process on sanctions, with the exception of Belgium. The centrality of the ME and the MFA is widely acknowledged.
However, this is a rather superficial understanding of who makes the decisions in the various member states: Those involved include interministerial commissions, subgroups, and technical agencies. These, among others, enjoy various degrees of influence in the sanctions decision-making cycle. Examples can be found, inter alia, in Italy with the Financial Security Committee, set up at Italy's Ministry of Economy and Finance according to Legislative Decree 109/2007; in Malta, as mentioned above, where Article 7 of the National Interest (Enabling Powers) Act states that the functions outlined earlier are attributed to the Sanctions Monitoring Board, a separate, independent government body; and in Bulgaria, where such competences are granted to the chairperson of the National Security State Agency and the director of the Customs Agency, among other institutions, according to Article 67 of the Defence-related products and dual-use items and technologies export control Act. We found little evidence of bottom-up approaches (i.e., convergence and networking), since member states appear to favour a more centralized approach. This means that, in practice, the degree of transposition and application variance occurring across EU member states might jeopardize the optimal functioning of the internal market, potentially having a direct impact on the effectiveness of sanctions as a foreign policy instrument per se.

Council Regulations on sanctions matters affect the internal market primarily because they allow member states to offer less stringent rules for export than other EU peers. If penalties are substantially lower in one country compared to others, then companies will have an incentive to set up branches and subsidiaries in certain member states in order to carry out trade that would be too risky elsewhere in the EU. While uneven transposition does not necessarily affect internal trade, it creates a structure of incentives favouring some states over others. Similarly, the institutional architecture that supports the implementation phase of the sanctions cycle also creates incentives for firms, companies, but also NGOs to opt for operating out of certain EU member states over others. For instance, in a situation where the capacity of a certain administration remains undeveloped, the chances of receiving an export licence or complete information are lower. A study on the internal redistributive impact of EU sanctions on Russia shows that while these restrictive measures were supposed to reduce trade therewith across the board, related exports in some sectors by certain member states actually increased (Giumelli, 2017). Uneven transposition and uneven application might help explain this phenomenon.

If the EU sanctions regime can be easily circumvented or legally avoided, the result is that trade which should never happen in fact regularly occurs, undermining the ultimate effectiveness of sanctions. The most common indicator for the impact of sanctions is either the overall effect on the economy or a reduction in trade within the specific sector targeted by these restrictive measures. If economic operators find ways to carry out trade in 
prohibited sectors, whether they do it from within the EU or not, then sanctions' impact is affected. Frequently, restrictive measures seek to deny access to certain products/technology. Therefore, it is not the quantity of trade that matters, but whether one specific good arrives at its destination. If all it takes for companies to reduce their risks is carrying out their exports from a member state presenting them with virtually no danger of being caught, then the chances of success for a sanction regime are slim. There will always be "the transaction" that is not supposed to take place. Moreover, in such cases there is a reputational cost for the EU too, to be added to the low effectiveness of EU external action caused by unevenly transposed restrictive measures.

\section{Conclusions}

The analysis of the implementation of EU restrictive measures across member states has provided empirical confirmation of the uneven transposition and application of a key CFSP policy instrument throughout the Union's territory. By looking at the penalties designed to punish sanctions violators imposed in respective member states, we have identified that, on paper, operators face very different risk scenarios if caught in violation of sanctions depending on the EU member state they are based in. This uneven playing field does not only hold true for risks but also for institutional coherence and consistency across the territory of the EU. This means that economic operators may be either penalized or supported when trading with countries or targets to which restrictive measures apply depending on the member state where they are based.

The findings of this article are twofold. First, we claim that implementation and compliance studies should involve CFSP decisions more systematically in their scholarship. The connection between trade and foreign policy has reached such a degree that the institutional architecture of the EU has also started to adapt to this new scenario. It is not by accident that transposition competences on sanctions matters have been recently moved back to the Directorate-General on Financial Stability, Financial Services and Capital Markets Union (DG-FISMA) of the Commission from the External Action Service. Second, we provide empirical confirmation of how uneven transposition and application occurs across the EU. While uneven transposition had been assumed to be a problem of sanctions per se, this research has brought forth a novel empirical account of how the delegation of tasks to member states can lead to uneven implementation.

This is, necessarily, the first of several studies that should be carried out in this emerging research field. For instance, future analyses need to go beyond the law inscribed on paper and focus on application and enforcement instead. When it comes to application, focus needs to be on the degree of freedom to interpret EU regulations by national competent authorities. Enforcement studies must investigate the extent to which administrative and criminal penalties have actually been imposed over time. Moreover, the findings of this research invite further studies explaining why implementation performance varies across EU member states.

Given the clear link with the internal market, future scholarship should focus on the role of EU institutions regarding the monitoring of how member states implement Council Regulations even when inspired by CFSP decisions adopted under Article 29 of the TEU. As the CJEU appropriated some competences in the Kadi case (Isiksel, 2010), the Commission could start to play a more active role. Finally, if uneven implementation is problematic, potential solutions to this problem should now be investigated. While attention should be paid to the motivations and capabilities of member states, even more besides should be devoted to scrutinizing whether this is the best possible equilibrium between the need for a coherent top-down policy set by EU institutions and the intricacies of an on-the-ground reality that-especially in the CFSP-is characterized by incomplete information.

\section{Acknowledgments}

We thank the members of the Chair Group on History and Theory of European Integration at the Department of International Relations and International Organization of the University of Groningen for their comments and suggestions. This article was also presented at the ECPR Joint Session in May 2021, where it was extensively discussed and for which we thank all participants and the Joint Session convenors. We especially thank the editors and the anonymous reviewers for their invaluable comments. All errors remain our own.

\section{Conflict of Interests}

The authors declare no conflict of interests.

\section{Supplementary Material}

Supplementary material for this article is available online in the format provided by the author (unedited).

\section{References}

Bache, I. (1999). The extended gatekeeper: Central government and the implementation of EC regional policy in the UK. Journal of European Public Policy, 6(1), 28-45.

Bicchi, F. (2010). Dilemmas of implementation: EU democracy assistance in the Mediterranean. Democratization, 17(5), 976-996.

Blom-Hansen, J. (2005). Principals, agents, and the implementation of EU cohesion policy. Journal of European Public Policy, 12(4), 624-648.

Bondarouk, E., \& Mastenbroek, E. (2018). Reconsidering EU compliance: Implementation performance in 
the field of environmental policy. Environmental Policy and Governance, 28(1), 15-27. https://doi.org/ 10.1002/eet.1761

Börzel, T. A. (2021). Why noncompliance. The politics of law in the European Union. Cornell University Press.

Börzel, T. A., \& Buzogany, A. (2019). Compliance with EU environmental law. The iceberg is melting. Environmental Politics, 28(2), 315-341.

Börzel, T. A., Hofmann, T., Panke, D., \& Sprungk, C. (2010). Obstinate and inefficient: Why member states do not comply with European law. Comparative Political Studies, 43(11), 1363-1390.

Bugdahn, S. (2005). Of Europeanization and domestication: The implementation of the environmental information directive in Ireland, Great Britain and Germany. Journal of European Public Policy, 12(1), 177-199.

Chatzopoulou, S. (2015). When do national administrations adapt to EU policies? Variation in Denmark and Greece. International Journal of Public Administration, 38(2), 104-115.

Commission Implementing Regulation (EU) 2019/1163 of 5 July 2019 amending and setting out a single list for the Annexes containing contact details of Member States competent authorities and address for notifications to the European Commission to certain Regulations concerning restrictive measures. (2019). Official Journal of the European Union, L 182.

Council Common Position 2008/944/CFSP of 8 December 2008 defining common rules governing control of exports of military technology and equipment. (2008). Official Journal of the European Union, L 335.

Council Regulation (EC) No 428/2009 of 5 May 2009 setting up a Community regime for the control of exports, transfer, brokering and transit of dual-use items. (2009). Official Journal of the European Union, L 134. https://eur-lex.europa.eu/legal-content/EN/ TXT/PDF/?uri=CELEX:02009R0428-20171216\& from $=\mathrm{EN}$

Cowles, M. G., Caporaso, J. A., \& Risse, T. (2001). Transforming Europe: Europeanization and domestic change. Cornell University Press.

de Vries, A. W., \& Hazelzet, H. (2005). The EU as a new actor on the sanctions scene. In P. Wallensteen \& C. Staibano (Eds.), International sanctions: Between words and wars in the global system (pp. 95-107). Frank Cass.

Di Lucia, L., \& Kronsell, A. (2010). The willing, the unwilling and the unable-Explaining implementation of the EU Biofuels Directive. Journal of European Public Policy, 17(4), 545-563.

Dörrenbächer, N. (2017). Europe at the frontline: Analysing street-level motivations for the use of European Union migration law. Journal of European Public Policy, 27(9), 1328-1347.

Drulakova, R., \& Zemanova, S. (2020). Why the implementation of multilateral sanctions does (not) work: Lessons learned from the Czech Republic. European
Security, 29(4), 524-544.

Duina, F. (1997). Explaining Legal Implementation in the European Union. International Journal of the Sociology of the Law, 25, 155-179.

Eckes, C. (2008). Judicial review of European antiterrorism measures-The Yusuf and Kadi judgments of the Court of First Instance. European Law Journal, 14(1), 74-92.

Eriksson, M. (2011). Targeting peace: Understanding UN and EU targeted sanctions. Ashgate.

European Union. (2004). Basic principles on the use of restrictive measures (sanctions) (10198/1/04 (Generic)). http://register.consilium.europa.eu/doc/ srv?l=EN\&f=ST\%2010198\%202004\%20REV\%201

European Union. (2018a). Guidelines on implementation and evaluation of restrictive measures (sanctions) in the framework of the EU Common Foreign and Security Policy (5664/2018(Generic)).

European Union. (2018b). Restrictive measures (sanctions) update of the EU Best Practices for the effective implementation of restrictive measures (8519/18(Generic)).

Falkner, G., Hartlapp, M., Leiber, S., \& Treib, O. (2004). Non-compliance with EU directives in the member states: Opposition through the backdoor? West European Politics, 27(3), 452-473.

Falkner, G., Treib, O., Hartlapp, M., \& Leiber, S. (Eds.). (2005). Complying with Europe: EU harmonisation and soft law in the member states. Cambridge University Press. vGiumelli, F. (2013). Beyond intergovernmentalism: The Europeanization of restrictive measures? Journal of Contemporary European Reserach, 9(3), 390-405.

Giumelli, F. (2017). The redistributive impact of restrictive measures on EU members: Winners and losers from imposing sanctions on Russia. Journal of Common Market Studies, 55(5), 1062-1080.

Giumelli, F. (2019). Implementation of sanctions: European Union. In M. Asada (Ed.), Economic sanctions in international law and practice (pp. 116-135). Routledge.

Giumelli, F., Hoffmann, F., \& Książczaková, A. (2021). The when, what, where and why of European Union sanctions. European Security, 30(1), 1-23.

Gollata, J. A. M., \& Newig, J. (2017). Policy implementation through multi-level governance: Analysing practical implementation of EU air quality directives in Germany. Journal of European Public Policy, 27(9), 1308-1327.

Hartlapp, M., \& Leiber, S. (2010). The implementation of EU social policy: The "Southern Problem" revisited. Journal of European Public Policy, 17(4), 468-486.

Heidbreder, E. G. (2017). Strategies in multilevel policy implementation: Moving beyond the limited focus on compliance. Journal of European Public Policy, 24(9), 1367-1384. https://doi.org/10.1080/ 13501763.2017.1314540

Héritier, A. (2001). Differential Europe: The European 
Union impact on national policymaking. Rowman \& Littlefield.

Hjern, B. (1982). Implementation research: The link gone missing. Journal of Public Policy, 2(3), 301-308.

Isiksel, T. N. (2010). Fundamental rights in the EU after Kadi and Al Barakaat. European Law Journal, 16(5), 551-577.

Kreutz, J. (2005). Hard measures by a soft power? Sanctions policy of the European Union (Paper No. 45). Bonn International Center for Conversion. https:// www.bicc.de/uploads/tx_bicctools/paper45.pdf

Lipsky, M. (1980). Street level bureaucracy: Dilemmas of the individual in public services. Russel Sage Foundation.

Lohmann, S., \& Vorrath, J. (2021). International sanctions: Improving implementation through better interface management (Working Paper No. 01). Stiftung Wissenschaft und Politik. https://www.swpberlin.org/publications/products/arbeitspapiere/ WP_International_Sanctions.pdf

Mastenbroek, E. (2005). EU compliance: Still a "black hole"? Journal of European Public Policy, 12(6), 1103-1120. https://doi.org/10.1080/13501760500 270869

Meter, D. S. V., \& Horn, C. E. V. (1975). The policy implementation process: A conceptual framework. Administration \& Society, 6(4), 445-488. https://doi.org/ $10.1177 / 009539977500600404$

Portela, C. (2007). Aid suspensions as coercive tools? The European Union's experience in the AfricanCaribbean-Pacific (ACP) context. Review of European and Russian Affairs, 3(2), 38-53.

Portela, C. (2010). European Union sanctions and foreign policy: When and why do they work? Routledge.

Pressman, J., \& Wildavsky, A. (1984). Implementation: How great expectations in Washington are dashed in Oakland. University of California Press.

Rossel, L., Unger, B., \& Ferwerda, J. (2021). Shedding light inside the black box of implementation: Tax crimes as a predicate crime for money laundering. Regulation \& Governance. Advance online publication. https:// doi.org/10.1111/rego.12407
Sabatier, P., \& Mazmanian, D. (1979). The conditions of effective implementation: A guide to accomplishing policy objectives. Policy Analysis, 5(4), 481-504.

Sampson Thierry, J., \& Sindbjerg Martinsen, D. (2018). Lost in translation: How street-level bureaucrats condition Union solidarity. Journal of European Integration, 40(6), 819-834.

Schmälter, J. (2019). A street-level perspective on noncompliance in the EU: New lessons to draw? Journal of Contemporary European Studies, 27(1), 1-14. https://doi.org/10.1080/14782804.2018.1519486

Siegel, S. (2011). The political economy of noncompliance: Adjusting to the single European market. Routledge.

Steunenberg, B., \& Toshkov, D. (2009). Comparing transposition in the 27 member states of the EU: The impact of discretion and legal fit. Journal of European Public Policy, 16(7), 951-970. https://doi.org/ 10.1080/13501760903226625

Sverdrup, U. (2005). Implementation and European integration: A review essay (Working Paper No. 25). ARENA Centre for European Studies. https://www.sv. uio.no/arena/english/research/publications/arenaworking-papers/2001-2010/2005/wp05_25.pdf

Thomann, E., \& Sager, F. (2017). Toward a better understanding of implementation performance in the EU multilevel system. Journal of European Public Policy, 24(9), 1385-1407. https://doi.org/10.1080/ 13501763.2017.1314542

Thomann, E., \& Zhelyakova, A. (2017). Moving beyond (non-)compliance: The customization of European Union policies in 27 countries. Journal of European Public Policy, 27(9), 1269-1288.

Treib, O. (2014). Implementing and complying with EU governance outputs. Living Review in European Governance, 9(1). http://www.europeangovernancelivingreviews.org/Articles/Ireg-2014-1

Versluis, E., Keulen, M. van, \& Stephenson, P. (2011). Analyzing the European Union policy process. Palgrave Macmillan.

Wunderlich, D. (2012). The limits of external governance: Implementing EU external migration policy. Journal of European Public Policy, 19(9), 1414-1433.

About the Authors

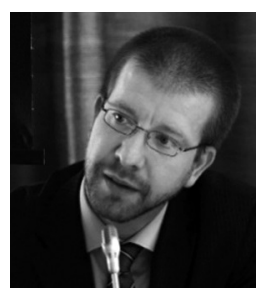

Francesco Giumelli is associate professor of international relations and international organization at the University of Groningen in the Netherlands. He wrote Coercing, Constraining and Signalling: Explaining UN and EU Sanctions After the Cold War (ECPR Press) and The Success of Sanctions (Routledge). His research interests are international sanctions and illicit trade.

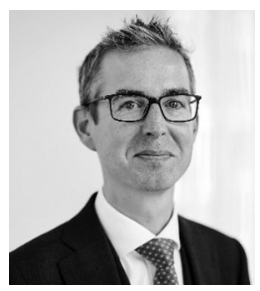

Willem Geelhoed is associate professor of criminal law and criminal procedure at the University of Groningen. He is also a deputy appeals judge at the Arnhem-Leeuwarden Court of Appeal and a member of the Meijers Committee. His teaching and research are focused on European criminal law, international cooperation in criminal matters, and organised and financial crimes. 


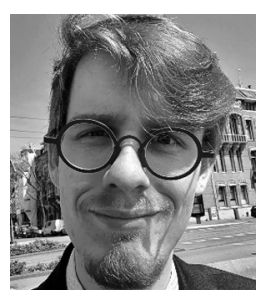

Max de Vries is a PhD student at the University of Groningen. His research concerns the determination of dangerousness in Dutch criminal law.

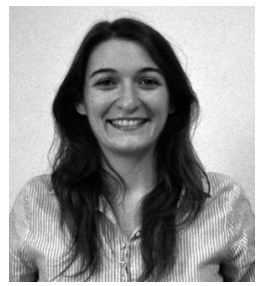

Aurora Molesini is a Master student at the University of Bologna. She has a BA degree on European Languages and Cultures and her research interests are European sanctions. 